\title{
Relative Importance of some Natural Products acting as Pesticides Alternatives against Tetranychus urticae Koch, (Tertranychidae : Acari)
}

A.M.Hussein, H.M.El-Nenaey, S.A.Allam, Ghada.E.Abdallah, El sayeda H. El kasser .
Plant Protection Research Institute (PPRI), Agricultural Research Center (ARC), Egypt .

\begin{abstract}
Eight kinds of natural botanical origin oils (three fixed and five essential) were investigated through lab. experiment and another field applied experiment on the Tetranychus urticae in kidney beans plantations. The two main techniques: 1 - dipping disc bioassay and 2- spray.Observations lasted along the life cycle.Number of dead individuals and their percentages during the first 3 days were taken as indicator for the ascending ranking of the eight kinds of oils, in comparison with water as a control.Results of the lab. experiments revealed that the eight investigated compounds were categorized in 3 groups: The first one include Ginger, Garlic and Thyme oil with mortality percentage 58.33, 53.33 and 52.22\%, respectively. The second group, have a medium effect contains: Sun - flower seed, row cotton seed and linseed oil, respectively. The Third group contains basil and mandrine oil which recorded the lowest values directly before the control treatment.

Results also showed that the total numbers of dead individuals in dipping technique were considerably higher than those of spray case. The three (3) oils of first group were conducted in a field experiment to spray kidney been plantation in, Kafr el Tawila, village, Dakahila Governorate against T.urticae. Results showed that garlic oil was the highest effect followed with thyme and ginger oils, respectively.
\end{abstract}

Key words: Pesticide alternatives-Fixed oils- essential oils- Tetranychus urticae.

\section{Introduction}

Using essential and Fixed oils to control pests is a recent trend to creat more pesticides alternatives.It is well known that some of both botanical essential and or fixed oils have their importance as phytotherapy agents for their content of antioxidants and other medicinal compounds. (Gulcin et al 2007), in addition, these oils played a considerable role to be pesticides alternatives against some important pests e.g. the two spotted spider mite and other pests.

Cloyd et al. (2009) conducted a quantitative study which demonstrated that the commercially plant- derived essential oils products vary in their effectiveness against some arthropods pests. They also indicated efficacy phytotoxicity of these plantderived essential oil products on arthropod pests including T.urticae. Results indicated that mite product, which contains (cotton seed, dove, and garlic oil) was most effective against the two- spotted spider mite $>90 \%$ mortality.

Nath and Sapna Mahajan (2005) in their studies to control $T$. urticae, invertigated azadirachtin and garlic oils. It was reported that these extracts were safety to natural enemies of the phytophagous mite species in comparison of fenazaquin, which showed maximum toxicity .Abbasy et.al (1998) in their studies, investigated the toxical effect of some plant extracts e.g. Pancratium maritimum and soosan on some pests e.g. Aphis gassypii, Spodotera littoralis, Culex pipiens and T.urticae.

They reported that, the oil of soosan bulbs was toxic to T.urticae. In addition they found that there was a synergistic effect for the principal alkaloid of seasan bulbs, when added to cyanophos, reducing its $\mathrm{Lc}_{50}$ value from 120 to $48 \mathrm{ppm}$. only on A. gossypii. This study aimed to investigate eight (8) of botanical origin essential and fixed oils on the two-sppoted spider mite Tetranychus urticae in laboratory and field.

\section{Materials and Methods}

To evatuate the effect of the 8 botanical origin oils on T.urticae.Three (3) of the investigated oils were fixed oils obtained by seeds cold press method, while the other (5) oils were essentials (volatile) oils obtained by vapour distillation method The eight investigated oils represented 8 treatments as follow: 1- Raw cotton seed oil (A), 2-Mandrine oil (Citrus leaves pure oil) (B), 3- pure basil oil (C), 4- Linseed oil (D), 5- Thyme oil (E), 6- Ginger oil (F), 7- Sun flower seed oil (G) and 8- Garlic oil (H). The solutions for dipping and spray were prepared using $1 \mathrm{ml}$ of the pure oil per 1 liter of distilled water and $2 \mathrm{ml}$ of artificial detergent as a diffusion material, in addition to control treatment (dipping in and spray with: 9- water (I).The fixed oils were: raw cotton seed, linseed and sun-flower oil. The two bio-assay main techniques followed were: 1- leaf - disc dipping and 2- spraying discs. In both, (10) ten adult individuals of T.urticae were carefully taken from a previously prepared lab. culture reared on the room temperature $25 \pm 2^{\circ} \mathrm{c}$ and $75 \%$ relative humidity.

A- lab experiment: in lab. dipping and spray was carefully carried out to ensure equal time of disc dip in the solution and homogeneity of spraying drops. Ten (10) adult mite individuals were carefully 
transferred to each disc, three (3) discs were used per 1 petri-dish and 3 dishes were used per each treatment. Number of living and dead individuals were recorded. Total numbers and percentages of dead individuals for each treatment after 24,48 and 72 hours was the main indicator to consider the ascending ranking of the treatment. Ranking in case of spray (Rs) and in case of dipping ( $\mathrm{Rd}$ ) were used to calculate the final ranking $(\times \mathrm{R})$ as an average of the two values using it to ascending rank for the nine treatments. Three tests were repeated each test have 3 replicates and the average values and standard deviation (SD) were calculated.

Gorski and Piatek (2008) studied the effect of natural essential oils i.e. geranium, lavender, peppermint, pine and thyme oil in the control of twospotted spider mite occurring on dwarf bean. Mortality of the pest was evaluated 24, 48 and 72 hours after treatment. Applications of the oils were at concentrations of $0.02,0.05$ and $0.1 \%$ for peppermint and geranium and of 0.05 and $0.1 \%$ for thyme oil, while applications for lavender were of 0.02 and $0.05 \%$. In their results they reported that using of the tested essential oils resulted $92.7-99.8 \%$ mortality for 72 hours treatment.

B-The field experiment: the most three (3) effective oils, as deduced from the lab. work: thyme, ginger and garlic oils were used in a completely random experiment in (Kafr el tawela) village, Mansoura, Dakahlya governorate, North-eastern Delta.

In this field experiment, kidney-bean plants of 45 days age were sprayed against T.urticae. three replicates of (36) leaves samples were collected and investigated 1,3 and 7 days after spray. A new ascending ranking for these 3 treatments was considered. (Table 4)

\section{Results and Discussion}

Results show that total numbers of dead individuals of T.urticae within 3 days in dipping method through 3 tests, (each have 3 replicates) were about $28 \%$ higher than those of spray for the whole treatments.

Table (1) shows the effect of spray in all treatments and mortality percentage for the different oils. Ascending ranking (Rs) was considered according to the mortality values. Ginger oil occupied the first rank as it recorded $47.78 \%$ followed with Garlic and sun- flower oils with $43.33 \%$ and $41.67 \%$ respectively.

It seems that this 3 pre-mentioned oils represents the first group with the highest value of efficiency. The second groups of oils with a moderate effect on the T.urticae individuals were: linseed and thyme oil with $35 \%$ mortality percentage for both of them, in addition to raw cotton seed oil with $32.78 \%$, which recorded the $5^{\text {th }}$ ranking of all treatments. Basil oil and mandrine recorded $6^{\text {th }}$ and $7^{\text {th }}$ ranking with 31.11 and $29.89 \%$, respectively directly come before the control treatment. Table 2 indicates the similar data e.g. the total dead individuals of T.urticae affected by the same treatments through dipping discs in the prepared solutions. In addition ranking of the treatments $(\mathrm{Rd})$ was recorded.

Data show that the first group of oils, with the high effect on T.urticae were: Thyme, Ginger and Garlic oils with mortality percentage 69.44, 68.88 and $63.33 \%$, respectively.

Also the same table shows that, the second group of oils, with a medium effect on the T.urticae individuals were Sun flower seed oil, Raw cotton seed oil and Basil oil, in the $4^{\text {th }}, 5^{\text {th }}$ and $6^{\text {th }}$ ranking with mortality, percentage 52.22, 37.22 and $36.11 \%$, respectively.

About linseed oil and mandrine oil the results recorded near values of mortiality percentage 33.89 and $32.22 \%$ respectively while the control treatment recorded $3.33 \%$ only.

Kazem and El-Sherief(2010) investigated toxicity of some plant extracts e.g. capsicum and garlic in some pests e.g. aphids and red mite. In their studies they reported that using these two extracts in the boiled linseed oil increased the effectiveness of boiled linseed oil opposite the effectiveness of boiled linseed oil against the red mite.

The acaricidal effects of some essential and fixed oils on the two - spider mite, T.urticae were investigated by Ismail et al. (2011). In their studies a comparison was made for studying the effect of the essential oils : Rosemasy, garlic, Jojoba and a fixed the highest significant decrease in the numbers of deporited eggs as compared to the other tested oils. Vegetable oil greatly affected the percentage of number that reached adults, followed by Jojoba oil then garlic oil while rose mary had no effect on nymph's developments.

Table (3) shows that the final ranking for the eight (8) oil compounds (RR) which was the average values of spray and dipping rank. Ginger, Garlic and Thyme oils occupied the $1^{\text {st }}, 2^{\text {nd }}$ and $3^{\text {rd }}$ ranks with an average mortality percentage $58.33,53.33$ and $52.22 \%$, respectively. The second group of oils with medium effect on T. urticae was Sun- flower seed oil, Raw cotton seed and linseed oil with 46.95, 35.00 and $34.45 \%$, respectively.

Basil and Mandrine oil recrded the lowest values 33.61 and $31.06 \%$ respectively and comes directly before the control treatment, which was only $8.89 \%$ (fig.1).Table (4) show that the result of field experiment which declared that garlic oil (I) was the most effective with $81.8 \%$ after 3 days followed with theyme (E) with only $31.6 \%$.

In order to control T.urticae lim Eu Gene et. al. (2011) investigated fumigation of 34 commercial essential oils on different stages of the mite, at 3 different temperatures 5,15 and $25 \mathrm{C}^{\circ}$. Results indicated that common thyme, cinnamon and lemon 
grass oils were equally effective on the adult stage showing 85.8 - $100 \%$ mortality at $25 \mathrm{C}^{\circ}$. Also it was reported that common thyme oil showed the highest ovicidal activity at $25 \mathrm{C}^{\circ}$. However, citrol oil was more active than other compounds to two- spotted spider mite eggs at $15^{\circ} \mathrm{C}$. Therefore it was concluded that citrol has the best potential for development as a fumigant against $T$. urticae on agricultural products harvested late in the growing season which carry botanical litters with mite eggs.

El Gengaihi et. al. (1996) studied the effect of thyme oil and thymol against T.urticae, it was concluded that, thymol was more potent than thyme oil as a factor to reduce egg laying by the mite. Mortality reached $100 \%$ with both materials used., even with low concentration the effect was more pronounced with theymol than thyme oil.

Table 1. Total numbers of dead individuals of Tetranychu s urticae (Td), Percentages (\%) and Ranking (Rs) of all treatments in spray lab. Technique.

\begin{tabular}{cccccccc}
\hline $\begin{array}{c}\text { Replicates } \\
\text { Treatments }\end{array}$ & $\boldsymbol{R} \boldsymbol{1}$ & $\boldsymbol{R} \boldsymbol{R}$ & $\boldsymbol{R 3}$ & $\boldsymbol{T o t a l}$ & $\boldsymbol{X} \pm \boldsymbol{S D}$ & $\boldsymbol{\%}$ & $\boldsymbol{R} \boldsymbol{}$ \\
\hline $\boldsymbol{A}$ & 24 & 21 & 14 & 59 & $19.67 \pm 4.19$ & 32.78 & 5 \\
$\boldsymbol{B}$ & 15 & 18 & 19 & 52 & $17.33 \pm 1.70$ & 29.89 & 7 \\
$\boldsymbol{C}$ & 25 & 19 & 21 & 65 & $21.67 \pm 2.49$ & 31.11 & 6 \\
$\boldsymbol{D}$ & 22 & 26 & 15 & 63 & $21.00 \pm 4.55$ & 35.00 & 4 \\
$\boldsymbol{E}$ & 17 & 25 & 21 & 63 & $21.00 \pm 3.27$ & 35.00 & 4 \\
$\boldsymbol{F}$ & 37 & 21 & 28 & 86 & $28.67 \pm 6.55$ & 47.78 & 1 \\
$\boldsymbol{G}$ & 19 & 28 & 28 & 75 & $25.00 \pm 4.24$ & 41.67 & 3 \\
$\boldsymbol{H}$ & 30 & 25 & 23 & 78 & $26.00 \pm 2.94$ & 43.33 & 2 \\
$\boldsymbol{I}$ & 9 & 9 & 8 & 26 & $8.67 \pm 0.47$ & 14.44 & 8 \\
\hline
\end{tabular}

Table 2. Total numbers of dead individuals of Tetranychus urticae (Td), Percentage (\%) and Ranking of all treatments in disc - dipping lab. Technique

\begin{tabular}{cccccccc}
\hline $\begin{array}{c}\text { Replicates } \\
\text { Treatments }\end{array}$ & $\boldsymbol{R} \boldsymbol{1}$ & $\boldsymbol{R} \boldsymbol{R}$ & $\boldsymbol{R 3}$ & $\boldsymbol{T o t a l}$ & $\boldsymbol{X} \pm \boldsymbol{S D}$ & $\boldsymbol{\%}$ & $\boldsymbol{R \boldsymbol { d }}$ \\
\hline $\boldsymbol{A}$ & 17 & 23 & 27 & 67 & $22.33 \pm 4.11$ & 37.22 & 5 \\
$\boldsymbol{B}$ & 26 & 19 & 13 & 58 & $19.33 \pm 5.31$ & 32.22 & 8 \\
$\boldsymbol{C}$ & 22 & 22 & 21 & 65 & $21.67 \pm 0.47$ & 36.11 & 6 \\
$\boldsymbol{D}$ & 17 & 26 & 18 & 61 & $20.33 \pm 4.03$ & 33.89 & 7 \\
$\boldsymbol{E}$ & 48 & 43 & 34 & 125 & $41.67 \pm 5.79$ & 69.44 & 1 \\
$\boldsymbol{F}$ & 48 & 36 & 40 & 124 & $41.33 \pm 4.99$ & 68.88 & 2 \\
$\boldsymbol{G}$ & 41 & 31 & 22 & 94 & $31.33 \pm 7.76$ & 52.22 & 4 \\
$\boldsymbol{H}$ & 44 & 32 & 38 & 114 & $38.00 \pm 4.90$ & 63.33 & 3 \\
$\boldsymbol{I}$ & 0 & 0 & 6 & 6 & $2.00 \pm 2.83$ & 3.33 & 9 \\
\hline
\end{tabular}

Raw cotton seed oil (A), Mandrline oil (Citrus leaves pure oil) (B), pure basil oil (C), Linseed oil (D)

Thyme oil (E), Ginger oil (F), Sun flower seed oil $(G)$, Garlic oil $(H)$, water (I)

Table 3. Ranking of all treatments in spray (Rs), dipping $(\mathrm{Rd})$ and average ranking $(\mathrm{RR})$ for the investigated oils according to their effect on T.urticae

\begin{tabular}{cccccc}
\hline $\begin{array}{c}\text { Ranking } \\
\text { Treatments }\end{array}$ & $\boldsymbol{R} \boldsymbol{s}$ & $\boldsymbol{R} \boldsymbol{d}$ & $\mathbf{X R}$ & $\boldsymbol{R} \boldsymbol{R}$ & $\boldsymbol{\%}$ \\
\hline $\boldsymbol{A}$ & 5 & 5 & 5 & 4 & 58.33 \\
$\boldsymbol{B}$ & 7 & 8 & 7.5 & 7 & 53.33 \\
$\boldsymbol{C}$ & 6 & 6 & 6 & 6 & 52.22 \\
$\boldsymbol{D}$ & 4 & 7 & 5.5 & 5 & 46.95 \\
$\boldsymbol{E}$ & 4 & 1 & 2.5 & 2 & 35.00 \\
$\boldsymbol{F}$ & 1 & 2 & 1.5 & 3 & 34.45 \\
$\boldsymbol{G}$ & 3 & 4 & 3.5 & 2 & 33.61 \\
$\boldsymbol{H}$ & 2 & 3 & 2.5 & 8 & 31.06 \\
$\boldsymbol{I}$ & 8 & 9 & 8.5 & & 8.89 \\
\hline
\end{tabular}




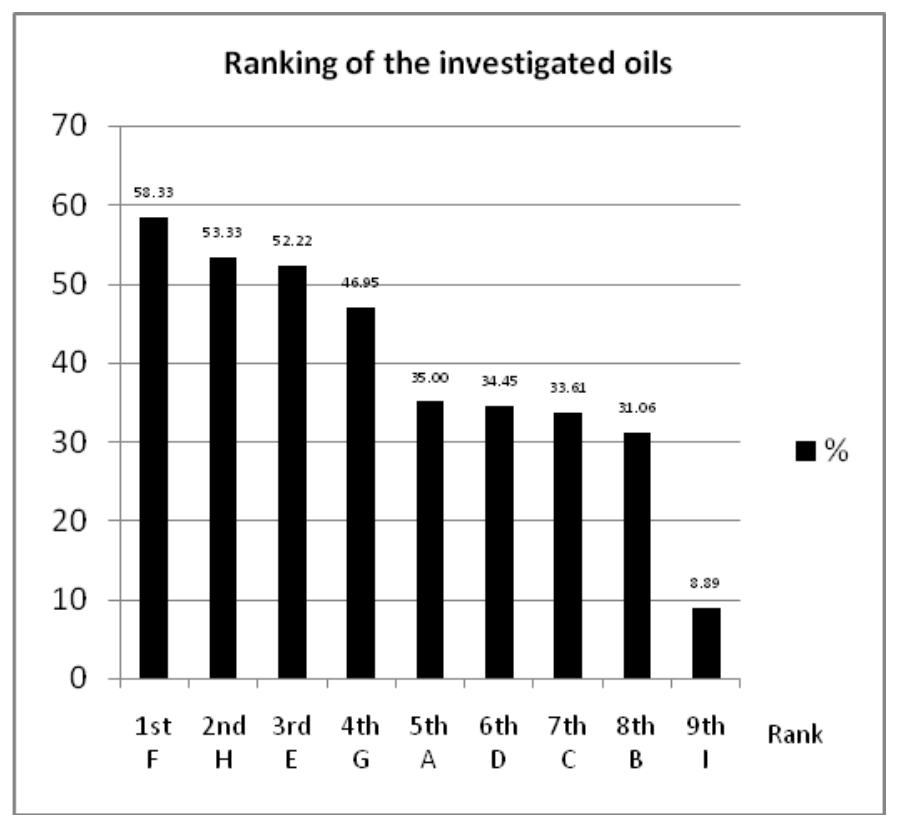

Table 4. The average numbers of live (L) and dead (D) individuals of T.urticae in the field experiment after 1,3 and 7 days of spray

\begin{tabular}{|c|c|c|c|c|c|c|c|c|c|c|c|c|}
\hline & \multicolumn{3}{|c|}{ Control } & \multicolumn{3}{|c|}{$\mathrm{Za}$} & \multicolumn{3}{|c|}{$\mathrm{Zn}$} & \multicolumn{3}{|c|}{$\mathrm{Gr}$} \\
\hline & $\mathrm{L}$ & D & $\%$ & $\mathrm{~L}$ & D & $\%$ & $\mathrm{~L}$ & $\mathrm{D}$ & $\%$ & $\mathrm{~L}$ & $\mathrm{D}$ & $\%$ \\
\hline 1 day & 51 & 17 & 25 & 31 & 14 & 31 & 13 & 5 & 27.7 & 20 & 21 & 51 \\
\hline 3 days & 61 & 12 & 16 & 13 & 6 & 31.6 & 6 & 2 & 25 & 2 & 9 & 81.8 \\
\hline 7 days & 57 & 27 & 32 & 14 & 7 & 33 & 14 & 2 & 12.5 & 19 & 5 & 20.8 \\
\hline
\end{tabular}

\section{References}

Abbassy, M. A.: El-Gougary, O. A.: El-Hamady, and S. Sholo, M. A.(1998). Insecticidal, acaricidal and synergistic effects of soosan, Pancratium maritimum, extracts and constituents. Journal of the Egyptian Society of Parasitology: 28(1): 197205.

Cloyd, R. A., Galle, C. L. Keith, S. R. Kalscheur, N. A. and Kemp, K. E. (2009). Effect of commercially available plant-derived essential oil products on arthropod pests. Journal of Economic Entomology: 2009. 102(4):1567-1579.

El-Gengaihi, S. E., Amer, S. A. A., and Mohamed, S. M.((1996).Biological activity of thymol against T.urticae Koch.Anzeiger fur Schadlingskunde, Pflanzenschutz, Umweltschutz; 69(7)):157-159.

Gorski, R. and Piatek, H. (2008).Efficacy of natural essential oils in the control of two-spotted spider mite (Tetranychus urticae Koch) occurring on dwarf bean. Progress in Plant Protection; 48(4): 1347-1350.
Gulcin, Ilhami, Elmastat Mahfuz Aboul-Enein, and Hassan Y. (2007). Determination of Antioxidant and Radical Scavenging Activity of Basil (Ocimum basilicum L. Family Lamiaceae) Assayed by Different Methodologies. Phytotherapy Research. 21(4) :354-361.

Ismail, M. S., M.Ghallab, M. M. A., Soliman, M. F. M. and Abo Ghalia, A.H. (2011). Acaricidal activities of some essential and fixed oils on the two-spotted spider mite, Tetranychus urticae. Egyptian Academic Journal of Biological Sciences - Zoology: 3(1):41-48.

Kazem, M. G. T. and El-Shereif, S. A. N.(2010).Toxic effect of Capsicum and garlic xylene extracts in toxicity of boiled linseed oil formulations against some piercing sucking cotton pests, American-Eurasian Journal of Agricultural and Environmental Science: 8(4):390-396.

Lim EuGene, Roh HyunSik, Coudron, T . A. and Park ChungGyoo(2011). Temperature-dependent fumigant activity of essential oils against twospotted spider mite 
(Acari:Tetranychidae).Journal of Economic Entomology: 104(2) :414-419.

Nath, A. and Sapna Mahakan (2005) Comparative in vitro evaluation of acaricides for intrinsic and persistent toxicity against mites Panonychus ulmi Koch and Tetranychus urticae Koch) on apple, Acta Horticulturae; (696):407-410.

$$
\begin{aligned}
& \text { الأهمية النسبية لبعض المواد الطبيعية كبدائل للمبيدات ضد العنكبوت الأحمر ذو البقعتين } \\
& \text { عبد الخالق محمد حسين - حسن محمد النعناعي - سعيد عبد العظيم علام - غادة السيد عبد اله - السيدة حلمى القصير. }
\end{aligned}
$$

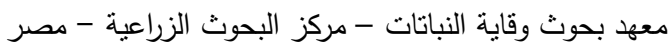

لدعم إتجاه إستخدام المركبات الطبيعية كبدائل للمبيدات فى مكافحة الآفات تم إختبار (8) ثمانية زيوت طبيعية ذات أصل نباتى لاراسة تأثيرها على العنكبوت الأحمر ذو البقعتين بإستخدام طريقتى: الرش والغمر لثرائح نباتية (ديسكات) فى أطباق بترى بالمعمل بهدف بيان الأهمية النسبية

$$
\text { للمعاملات تحت الفحص. }
$$

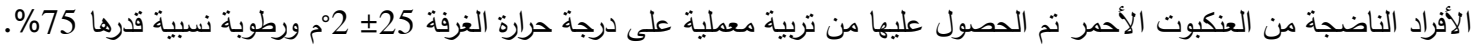

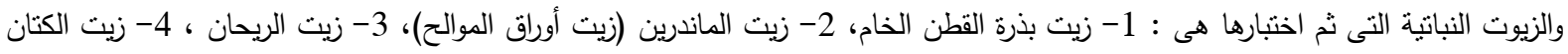

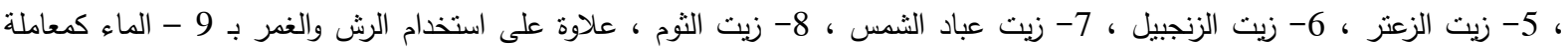
للمقارنة. وطبقاً لمدى نأثير المعاملة على العنكبوت الأحمر نم عمل نرتيب تصاعدي Ascending Ranking للمعاملات طبقاً للنسب المئوية

$$
\text { للأفراد الميتة. }
$$

وتم تصميم وتتفيذ تجربة حقلية كاملة العشوائية لرش أقوي ثلاث معاملات (طبقا لنتائج المعمل ) في الحقل علي نباتات الفاصوليا بقرية كفر

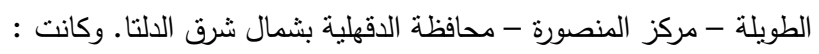

أ- نتائج التجارب المعملية: تقيد بأن مواد الرش الثمانية إنتظمت في ثلاث مجموعات : الأولي الأقوي ناثيراً وهي : تضم زيت الزنجبيل والثوم

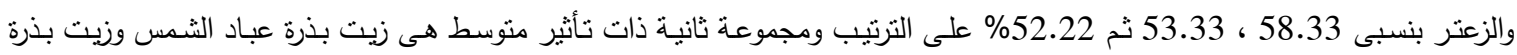

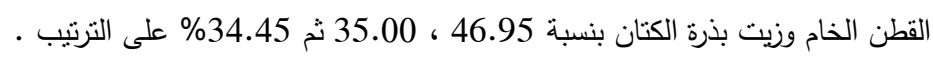

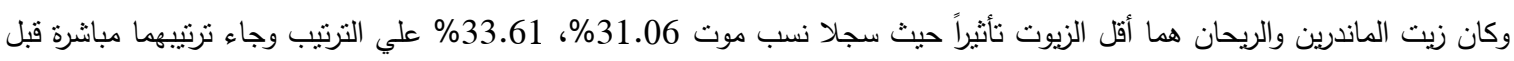

$$
\text { معاملة المقارنة (الرش والغمر بالماء). }
$$

ب- نتائج التجرية الحقلية: اظهرت تفوق زيت الثوم في قتل الأفراد بنسبة 81.8\% منبوعاً - وبفارق محسوس - بزيت الزعتر 31.6\% بينما لم

$$
\text { يظهر زيت الزنجبيل في الحقل تأثنيراً واضحاً. }
$$

